\title{
Stratifikasi dan Diferensiasi Dalam Kehidupan Sosial
}

M Chairul Basrun Umanailo ${ }^{1}$, Annisa Retrofilia Umanailo ${ }^{1}$, and Askar Daffa Sophia

Umanailo $^{1}$

${ }^{1}$ Affiliation not available

January 4, 2021

\section{Hosted file}

Stratifikasi_Dan_Diferensiasi_Dalam_.pdf available at https://authorea.com/users/310886/ articles/500597-stratifikasi-dan-diferensiasi-dalam-kehidupan-sosial 